\title{
Some Properties of Probiotic Yoghurt Ice Cream Supplemented with Carob Extract and Whey Powder
}

\author{
Mutlu B. Guler-Akin*, Busra Goncu, Musa Serdar Akin \\ Department of Food Engineering, Agricultural Faculty, Harran University, Şanlıurfa, Turkey \\ Email: *mutluakin@harran.edu.tr
}

How to cite this paper: Guler-Akin, M.B., Goncu, B. and Akin, M.S. (2016) Some Properties of Probiotic Yoghurt Ice Cream Supplemented with Carob Extract and Whey Powder. Advances in Microbiology, 6, 1010-1020.

http://dx.doi.org/10.4236/aim.2016.614095

Received: October 19, 2016

Accepted: December 13, 2016

Published: December 16, 2016

Copyright $\odot 2016$ by authors and Scientific Research Publishing Inc. This work is licensed under the Creative Commons Attribution International License (CC BY 4.0).

http://creativecommons.org/licenses/by/4.0/

\begin{abstract}
In this study, some properties of probiotic yoghurt ice cream supplemented with carob extract and whey powder and viability of $L$. acidophilus and Bifidobacterium $B B-12$ on ice-cream were investigated. For this purpose 6 different ice cream was produced with different ratios whey powder and carob extract. The viable probiotic bacteria counts were determined on $1^{\text {st }}, 7^{\text {th }}, 30^{\text {th }}, 60^{\text {th }}$ and $90^{\text {th }}$ days of storage. Addition of carob extract and whey powder significantly affected all properties of icecreams. Results showed that the most positive effect on physical, sensory and microbiological properties was observed on sample D which produced with $1 \%$ carob extract and $1 \%$ whey powder addition.
\end{abstract}

\section{Keywords}

Probiotic Yoghurt Ice-Cream, Carob Extract, Whey Powder

\section{Introduction}

Due to their attributed health benefits, probiotic bacteria (such as L. acidophilus and/or Bifidobacteria) have been increasingly applied in the dairy industry during the past two decades and are consumed at appropriate levels as part of a balanced diet. Many studies indicated that ice cream was an excellent vehichle for probiotic bacteria when compared to fermented dairy products [1]-[7]. However, probiotic organisms are unstable in such products. The loss of viability of probiotic organisms in a ice cream may be due to acidity, freeze injury and oxygen toxicity [2] [8]. Air incorparation is essential to obtain the desired overrun in ice cream; however excess oxygen will affect growth of microaeropfilic L. acidophilus and anaerobic Bifidobacteria [4]. In order to obtain therapeutic benefits, a suggested minimum level for probiotic bacteria in fermented milk was 
established and ranges from $10^{6}$ to $10^{7} \mathrm{CFU} / \mathrm{mL}$ [9] [10]. Therefore, manufacturers were interested in developing a process that can provide high densities of the probiotic strains in the product. For example, supplementing milk with a combination of protein hydrolysates, fructose whey protein concentrate, tomato juice and papaya pulp stimulated $L$. acidophilus, while cysteine, acid hydrolysates, tryptone, vitamins, dextrin and maltose improved the viability of Bifidobacteria. Prebiotics, such as oligosaccharides are added to food mainly to allow the preferential growth of probiotic organisms [11].

Carob (Ceratonia siliqua L.) is an evergreen tree belonging to the Leguminosae family, widely cultivated in the Mediterranean region, mainly Spain, Italy, Portugal, and Morocco [12] [13]. Seeds and pods of carob fruit are used as a raw material in industries such as food, pharmaceutical, and cosmetics ones [13]. The carob gum, also called locust bean gum (LBG) is obtained from seeds containing high amounts of galactomannans [12]. It is a valuable natural food thickener, stabilizer, and flavorant, which is commonly added to a variety of products, for example, ice creams, sweets, and soups [13] [14]. Raw carob pods and carob pod flour contain substantial amounts of polyphenols [15] [16] [17], especially condensed tannins [16] [18]. Polyphenols exhibit a wide range of biological properties, and among these, the antioxidant activity is the best known.

Whey powder contains amino acids such as cysteine, methionine, threonine. Dave and Shah [19] [20] and Klaver, Kingma and Weerkamp [21] have shown that milk supplemented with peptides and amino acids such as cysteine improved the survival of bifidobacteria. Cysteine is a sulphur-containing amino acid that is incorporated into agar media for the growth of bifidobacteria. Addition of this amino acid could improve the viability of anaerobic bifidobacteria [8].

The objective of this study was to improve the survival of the cells during freezing in probiotic ice cream by adding carob extract and whey powder and to determine their survival immediately after freezing and during storage. Furthermore, the effects of carob extract and whey powder levels on the physical and sensory characteristics of the probiotic ice-cream were also examined.

\section{Materials and Methods}

\subsection{Materials}

The non-fat milk powder (96\% total solids) (Pınar Dairy, Turkey), cream (35\% fat) (Tat Can Industry. A.S. SEK Plant, Turkey) and Lactobacillus acidophilus LA-5 (L. acidophilus) and Bifidobacterium animalis subsp. lactis BB-12 (Bifidobacterium BB-12) (Peyma-Chr. Hansen, Turkey) were used for ice cream production. Carrageenan (E 407), Guar gum (E 412), Xanthan gum (E 415) and Sodium alginate (E 401) (Sosa Ingredients, S.L. Ctra de Granera, Spain) were used as stabilizers. Lecithin was used as emulsifier and was obtained from Sosa Ingredients (S.L. Ctra de Granera, Spain). Sucrose $(100 \%$ TS) was used as a sweetener, and vanilla was added for aroma development. Carob extract and whey powder were obtained from Yeşil Deva and Maybi (Tekirdag, Turkey), respectively. All of the other used reagents were of analytical grade. 


\subsection{Ice Cream Manufacture}

Ice cream was formulated with the following composition (percentage by weight) such that it had $34 \%-35 \%$ total solids for a total batch of $5 \mathrm{~kg}: 11 \%$ non-fat total milk solid, $18 \%$ sugar, $5 \%$ fat, $0.8 \%$ stabilizers and $0.3 \%$ emulsifier. The mixes contain different ratios of whey powder and carob extracts (A: $0.5 \%$ whey powder, B: $1 \%$ whey powder, C: $0.5 \%$ whey powder $+1 \%$ carob extract, D: $1 \%$ whey powder $+1 \%$ carob extract, E: $1 \%$ carob extract, F: control). The milk and cream (35\% fat) were mixed and temperature brought to $45^{\circ} \mathrm{C}$, the skim milk powder, sugar, whey powder and carob extract, plus water, were added and pasteurized at $85^{\circ} \mathrm{C}$ for $1 \mathrm{~min}$. This mixes were homogenised at $85^{\circ} \mathrm{C}$ while stil hot, and allowed to cool to $40^{\circ} \mathrm{C}$. They inoculated with probiotic fermented milk at a rate of $5 \%$ and incubated at $37^{\circ} \mathrm{C}$ until pH 5.5 was attained. The probiotic ice-cream was produced by using a vertical freezing machine of $6 \mathrm{~kg}$ capacity (Uğur, Nazilli, Turkey). The partially frozen mix was packaged in 50, 100 and $200 \mathrm{~mL}$ cups and stored at $-18^{\circ} \mathrm{C}$. Manufacturing stages for the production of probiotic ice-cream is shown in Figure 1. The experiment was conducted in duplicate.

\subsection{Bacteriological Analysis}

Bacterial counts were determined fermented milk, immediately after mixing, and after freezing, at $7,30,60$ and 90 days of storage at $-18^{\circ} \mathrm{C}$. Fermented milk, mix and ice-cream samples $(10 \mathrm{~g})$ were decimally diluted in $100 \mathrm{~mL}$ sterile peptone water $(0.1 \%)$ and $1 \mathrm{~mL}$ aliquot dilutions were poured onto plates of the various selective and

$$
\text { Preparing of Mixes (A, B, C, D, E, F) }
$$

(Sugar, cream, skimmed milk powder, stabilizers, emulgator, water, whey powder,carob extract)

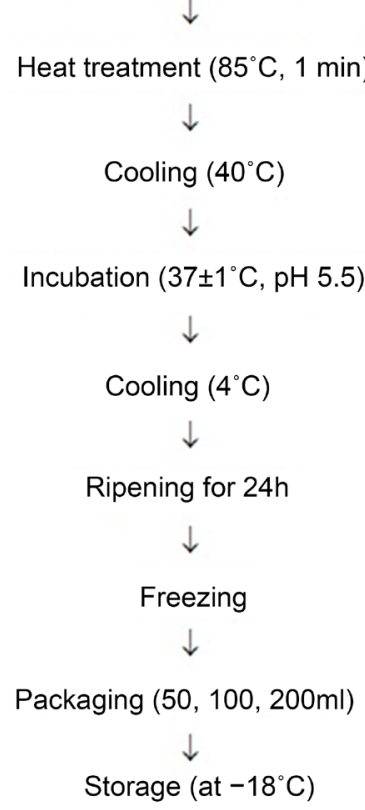

${ }^{*}$ A: $0.5 \%$ whey powder, B: $1 \%$ whey powder, C: $0.5 \%$ whey powder $+1 \%$ carob extract, D: $1 \%$ whey powder $+1 \%$ carob extract, $\mathrm{E}: 1 \%$ carob extract, $\mathrm{F}$ : control

Figure 1. Production of probiotic ice-cream. 
differential agars in triplicate. L. acidophilus and Bifidobacterium BB-12 were incubated by using MRS with sorbitol and MRS-NNLP agar, respectively [22] All plates were incubated anaerobically at $37^{\circ} \mathrm{C}$ for $72 \mathrm{~h}$. Anaerobic conditions were created using Anaerocult A sachets (Merck). The results were expressed as colony-forming units per gram $\left(\mathrm{cfu} \mathrm{g}^{-1}\right)$ of sample.

\subsection{Chemical Analysis}

The $\mathrm{pH}$ of the produced ice cream samples was measured using a digital $\mathrm{pH}$-meter and titratable acidity was determined according to the Soxhlet Henkel method [9]. The dry matter content of ice-cream samples was determined by drying the samples at $105^{\circ} \mathrm{C} \pm$ $1^{\circ} \mathrm{C}$ for overnight to a constant weight using an air oven [23]. The fat contents of ice cream samples were determined by the Gerber method [9].

\subsection{Physical Measurements}

The overrun of the final product was determined formulas follows [5]):

Overrun $=($ Weight of unit mix-weight of equal volume of ice cream $) /($ weight of equal volume of ice cream) ${ }^{\star} 100$

First dripping times were measured according to Güven and Karaca [24]. Meltdown rate was conducted according to Da Silva et al. [6]. $25 \mathrm{~g}$ of tempered samples were left to melt (at room temperature, $20^{\circ} \mathrm{C}$ ) on a $0.2 \mathrm{~cm}$ wire mesh screen above a beaker. The melted weight was recorded at the $30^{\text {th }}$, the $60^{\text {th }}$ and the $90^{\text {th }}$ minute. The viscosities of the ice-creams were determined at $4^{\circ} \mathrm{C}$ using a digital Brookfield Viscometer, Model DV-II (Brookfield Engineering Laboratories, Stoughton, MA, USA) [5].

\subsection{Sensory Assessment}

Sensory analysis of the ice-cream samples was assessed by ten untrained panellists. A 10 point hedonic scale was used to evaluate coldness, firmness, viscosity, smoothness, colour and appearance, mouth coating, flavour, taste and general acceptability $(1=$ strongly unacceptable, $10=$ very good) as described by Aime et al. [25]. The panel of assessors was an external panel (consisted of staff from the Harran University Department of Food Engineering, Turkey) of non-smokers who were very familiar with dairy products and were checked on the basis of sensory acuity and consistency. Each panellist received 7 samples of ice cream to taste and to evaluate the sensory characteristics at each serving. Panellists were also instructed to consume water between the samples in order to maintain discretion. Physical, chemical and sensory analyses were carried out 1 week after the production.

\subsection{Statistical Analysis}

Statistical analysis of data via one-way analysis of variance (ANOVA) was performed to check the significance of differences at $\mathrm{p}<0.01$ using SPSS Version5.0 (SPSS Inc. Chicago, IL, USA). Statistically different groups were determined by the LSD (Least Significant Difference) test [26]. 


\section{Result and Discussions}

\subsection{Bacterial Counts}

Figure 2 and Figure 3 show the variations in bacterial counts in fermented milk (12 h; milk fermented for 12 hours), mixes and probiotic ice-creams.

L.acidophilus and Bifidobacterium BB-12 counts of fermented milks were 8.11 and $8.95 \mathrm{log} \mathrm{cfu} \mathrm{g}^{-1}$. During freezing, the numbers of viable L. acidophilus and Bifidobacterium $\mathrm{BB}-12$ decreased by $0.71-0.99$ and $1.32-1.73$ log unit, respectively. It could be related to the result of freezing, is likely due to the freeze injury of cells, leading eventually to the death of cells. However, the mechanical stresses of the mixing and freezing

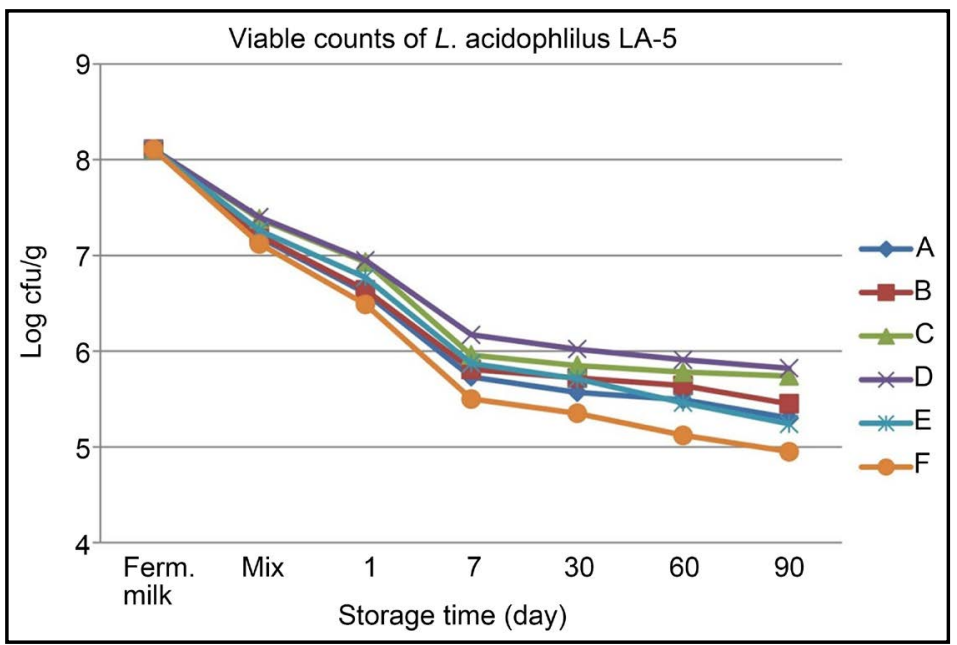

Figure 2. Viable counts of $L$. acidophilus in ice-cream with or without carob extract and whey powder addition during 90 days storage at $-18^{\circ} \mathrm{C}$. $\left({ }^{\star} \mathrm{A}\right.$ : $0.5 \%$ whey powder. B: $1 \%$ whey powder. C: $0.5 \%$ whey powder $+1 \%$ carob extract. D: $1 \%$ whey powder $+1 \%$ carob extract. E: $1 \%$ carob extract. F: Control).

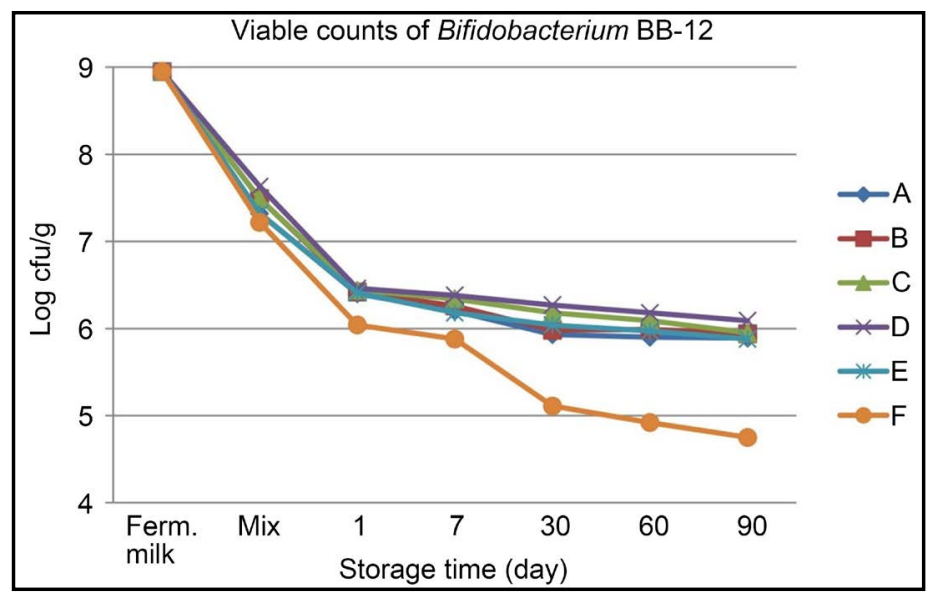

Figure 3. Viable counts of Bifidobacterium BB-12 in ice-cream with or without carob extract and whey powder addition during 90 days storage at $-18^{\circ} \mathrm{C}$. $\left({ }^{*} \mathrm{~A}: 0.5 \%\right.$ whey powder. B: $1 \%$ whey powder. C: $0.5 \%$ whey powder $+1 \%$ carob extract. D: $1 \%$ whey powder $+1 \%$ carob extract. E: $1 \%$ carob extract. F: Control). 
process and also the incorporation of oxygen into the mix, may have resulted in a further decrease in bacterial count. Previous reports show that oxigen toxicity caused by the incorporation of air during the ice cream production may seriously affect the growth of anaerobic bacteria [27] [28]. Similar results were reported by Akin [29], Akin, Akin and Kirmaci [5], Akalın and Erisir [30] and Ranadheera et al. [31] addition of carob extract and whey powder significantly affected the viable probiotic bacteria numbers was $(\mathrm{p}<0.01)$. The highest viable probiotic bacteria numbers were in the samples with $1 \%$ carob extract and whey powder (sample D). According to our results, addition of carob extract and whey powder improved the survival of $L$. acidophilus and Bifidobacterium BB-12 due to the possible prebiotic effects and antioxidant capacity of them. Lourens-Hattingh and Viljoen [11] reported that whey proteins and oligosaccharides had prebiotic effect.

L. acidophilus and Bifidobacterium BB-12 decreased in all samples during 90 days storage period $(\mathrm{p}<0.01)$. The decrease in the numbers of $L$. acidophilus and Bifidobacterium BB-12 in samples supplemented with carob extract and whey powder was less than those of the control and the other samples. The viable $L$. acidophilus counts at the end of 90 days storage period was under $10^{6} \mathrm{cfu}^{-1}$ in all the samples, however the viable Bifidobacterium BB-12 counts at the end of 90 days storage period was above the samples supplemented with $1 \%$ carob extract and whey powder (Sample D). Akin [29], Akin, Akin and Kirmaci [5], Akalin and Erisir [30], Ranadheera et al. [31] and Da Silva et al. [6] reported that the numbers of probiotic bacteria decreased during storage.

\subsection{Physico-Chemical Properties}

The some chemical properties of probiotic ice-creams were given in Table 1. The effect of carob extract and whey powder on the dry matter, $\mathrm{pH}$ and titratable acidity was significant $(\mathrm{p}<0.05)$. The dry matter contents $(\%)$ of the ice-cream slightly increased as the addition of carob extract and whey powder. It was observed that $\mathrm{pH}$ decreased and acidity increased in the samples supplied with carob extract and whey powder. Addition of mixture of carob extract and whey powder was more efective than individual addition of them to increase acidity. We concluded the addition of carob extract and whey powder of the fermented milk had stimulated the metabolic activities of probiotic bacteria and improved development of acidity.

Table 1. Some chemical properties of probiotic ice creams $(n=2)^{\star *}$.

\begin{tabular}{cccc}
\hline Samples* $^{*}$ & $\mathrm{pH}$ & Acidity (\%L.A) & Dry Matter (\%) \\
\hline A & $4.97 \pm 0.065^{\mathrm{a}}$ & $1.071 \pm 0.018^{\mathrm{ab}}$ & $31.23 \pm 0.14^{\mathrm{a}}$ \\
$\mathrm{B}$ & $4.93 \pm 0.005^{\mathrm{ab}}$ & $1.148 \pm 0.005^{\mathrm{bc}}$ & $31.61 \pm 0.11^{\mathrm{ab}}$ \\
$\mathrm{C}$ & $4.94 \pm 0.015^{\mathrm{ab}}$ & $1.116 \pm 0.009^{\mathrm{bc}}$ & $32.73 \pm 0.08^{\mathrm{c}}$ \\
$\mathrm{D}$ & $4.91 \pm 0.025^{\mathrm{ab}}$ & $1.152 \pm 0.023^{\mathrm{c}}$ & $32.84 \pm 0.07^{\mathrm{c}}$ \\
$\mathrm{E}$ & $4.97 \pm 0.040^{\mathrm{ab}}$ & $1.112 \pm 0.009^{\mathrm{bc}}$ & $31.97 \pm 0.03^{\mathrm{b}}$ \\
F & $5.03 \pm 0.040^{\mathrm{b}}$ & $1.022 \pm 0.014^{\mathrm{a}}$ & $31.11 \pm 0.11^{\mathrm{a}}$ \\
\hline
\end{tabular}

${ }^{*} \mathrm{~A}: 0.5 \%$ whey powder. B: $1 \%$ whey powder. C: $0.5 \%$ whey powder $+1 \%$ carob extract. D: $1 \%$ whey powder $+1 \%$ carob extract. E: $1 \%$ carob extract. F: Control; ${ }^{* a, b, c, M e a n s ~ i n ~ t h e ~ s a m e ~ c o l u m n ~ f o l l o w e d ~ b y ~ d i f f e r e n t ~ l e t t e r s ~ w e r e ~ s i g n i f-~}$ icantly different $(\mathrm{p}<0.01)$. 
The physical properties of ice-creams are shown in Table 2. Examinations of the viscosity, overrun value, first dripping time and melting rates of ice creams reveal significant differences among the control, the ice creams supplemented with carob extract and whey powder $(\mathrm{p}<0.01)$.

The samples supplemented with carob extract and whey powder had higher viscosity than control samples due to the high water binding capacity of them. As known carob gum is used as a stabilizer. On the other hand, whey proteins had high water holding capacity [32] [33]. The overrun values of samples treated with carob extract and whey powder were higher than the control samples. The sample supplemented with $1 \%$ carob extract and whey powder had the highest overrun value. The longest first dripping time was in the samples with $1 \%$ carob extract and whey powder. Our results indicate that first dripping time prolonged in addition of carob extract and whey powder. It could be related to they may act as a stabiliser due to their capacity for binding water. The result of this is that the water molecules become immobilized and unable to move freely among other molecules of the mix.

The meltdown characteristics are important quality parameters of probiotic ice cream [34]. Any samples melt in $30^{\text {th }}$ min. Several parameters influence the melting behavior, including the overrun [35], the fat content and use of fat replacers [36] [37], as well as the type of milk [38]. The samples supplemented with $1 \%$ carob extract and whey powder had the lowest melting rate in $60^{\text {th }}$ and $90^{\text {th }} \mathrm{min}$. It could be physical structure of ice cream. The three main structural components of ice cream are air cells, fat globules and ice crystals [31]. During storage of ice cream a number of changes in the physical structure of the product may potentially occur, such as disproportionation and coalescence of air cells [35] and ice recrystallization, whereby small ice crystals melt and large crystals grow simultaneously [30]. Small crystals, with a slightly lower melting point, are more sensitive to temperature fluctuations than large crystals [30], thus this phenomenon would be likely to affect the melting properties of the probiotic ice creams. We believe that addition of carob extract and whey powder provide the formation of small crystals.

Table 2. Physical properties of probiotic ice creams ${ }^{\star *}$.

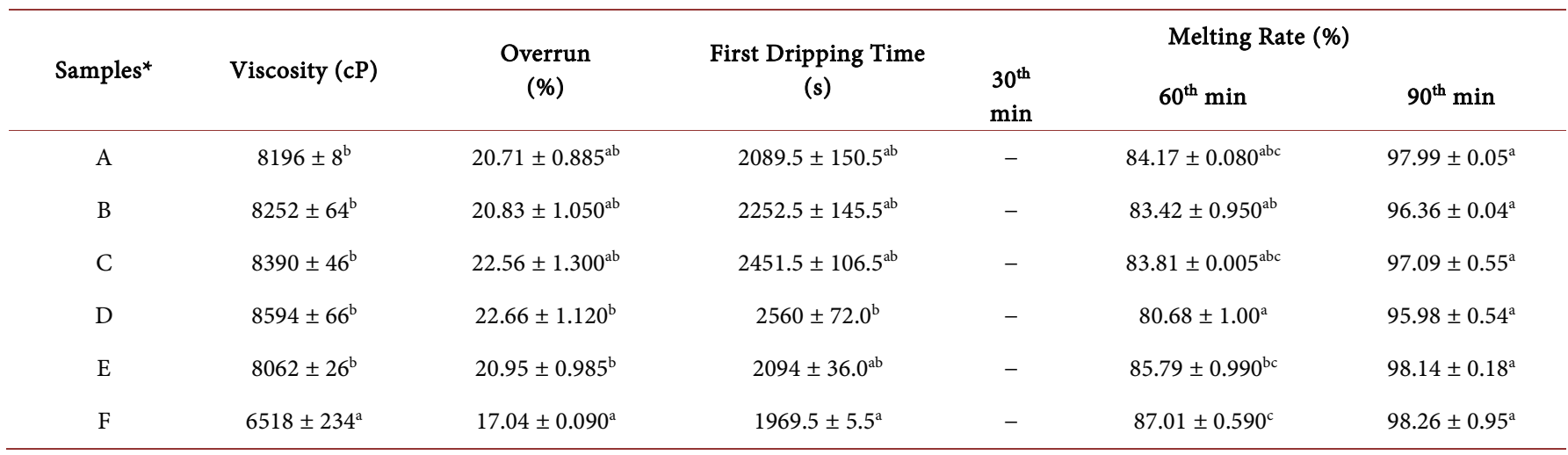

${ }^{*} \mathrm{~A}: 0.5 \%$ whey powder. B: $1 \%$ whey powder. C: $0.5 \%$ whey powder $+1 \%$ carob extract. D: $1 \%$ whey powder $+1 \%$ carob extract. E: $1 \%$ carob extract. F: Control; ${ }_{* * a, b, c}$ Means in the same column followed by different letters were significantly different $(\mathrm{p}<0.01)$. 


\subsection{Sensory Evaluations}

Addition of carob extract and whey powder had significant effect on the tested sensory characteristics (Table 3 ) of probiotic ice creams $(p<0.01)$. The points allocated for sensory evaluations showed that addition of carob extract and whey powder brought about an improvement in the coldness, firmness, viscosity, mouth coating, taste and odour and general acceptibility structure, of the products.

The lowest coldness was in the samples with $1 \%$ carob extract and whey powder. Coldness is related to large ice particles. When the water content increase, the larger ice particles formed in ice cream and the sensation coldness is intensify [25]. The carob extract and whey powder could be provided the formation of small crystals because of their potential stabilizer effects. The samples with $1 \%$ carob extract and whey powder had the highest firmness and viscosity scores. One reason for this could be the slightly higher dry matter of the samples. On the other hand, carob gum and whey powder had high water binding capacity [13] [14] [32] [33].

Control samples had the highest smoothness score. There is a decrease in smoothness score with increasing the whey powder addition. It could be related lactose content of whey powder. As known lactose caused coarse and sandy texture in ice cream.

Addition of carob extract decreased the colour and appearance scores of ice creams because of its colour from orange to brown. The highest mouth coating scores was the samples supplied with carob extract and whey powder. The improved mouthfeel of the samples containing carob extract and whey powder may be associated with decreased meltability.

Taste and odour score was greatest in sample $\mathrm{E}$ and least in sample B. It could be related to cheesy flavour of whey powder. When whey powder added with carob extract this flavour may be masked by carob extract. Control samples had the highest general acceptibility scores. It was followed by the sample supplemented with $1 \%$ carob extract and whey powder.

\section{Conclusions}

Addition of $1 \%$ carob extract and whey powder had improved on physical and sensory properties of ice cream. However, individual usage of whey powder had negatively

Table 3. Sensory evaluation of ice-creams $(n=2)^{\star *}$.

\begin{tabular}{ccccccccc}
\hline Sample* $^{*}$ & Coldness & Firmness & Viscosity & Smoothness & $\begin{array}{c}\text { Color and } \\
\text { appearance }\end{array}$ & $\begin{array}{c}\text { Mouth } \\
\text { coating }\end{array}$ & $\begin{array}{c}\text { Taste and odor } \\
\text { acceptability }\end{array}$ \\
\hline A & $5.28 \pm 0.23^{\mathrm{b}}$ & $7.33 \pm 0.325^{\mathrm{a}}$ & $6.35 \pm 0.95^{\mathrm{a}}$ & $7.17 \pm 0.055^{\mathrm{a}}$ & $9.36 \pm 0.025^{\mathrm{b}}$ & $7.14 \pm 0.135^{\mathrm{ab}}$ & $7.03 \pm 0.085^{\mathrm{ab}}$ & $7.39 \pm 0.055^{\mathrm{a}}$ \\
B & $5.00 \pm 0.12^{\mathrm{ab}}$ & $7.74 \pm 0.0350^{\mathrm{a}}$ & $6.46 \pm 0.045^{\mathrm{a}}$ & $7.44 \pm 0.060^{\mathrm{a}}$ & $9.25 \pm 0.085^{\mathrm{b}}$ & $7.22 \pm 0.110^{\mathrm{ab}}$ & $6.86 \pm 0.025^{\mathrm{a}}$ & $7.17 \pm 0.030^{\mathrm{a}}$ \\
C & $4.59 \pm 0.04^{\mathrm{ab}}$ & $7.90 \pm 0.065^{\mathrm{a}}$ & $6.77 \pm 0.045^{\mathrm{ab}}$ & $7.61 \pm 0.110^{\mathrm{a}}$ & $7.54 \pm 0.160^{\mathrm{a}}$ & $7.44 \pm 0.060^{\mathrm{b}}$ & $7.28 \pm 0.055^{\mathrm{bc}}$ & $7.19 \pm 0.165^{\mathrm{a}}$ \\
D & $4.47 \pm 0.03^{\mathrm{a}}$ & $8.04 \pm 0.170^{\mathrm{a}}$ & $6.97 \pm 0.030^{\mathrm{ab}}$ & $8.41 \pm 0.140^{\mathrm{b}}$ & $7.69 \pm 0.080^{\mathrm{a}}$ & $7.61 \pm 0.165^{\mathrm{b}}$ & $7.28 \pm 0.055^{\mathrm{bc}}$ & $7.77 \pm 0.110^{\mathrm{a}}$ \\
E & $4.79 \pm 0.13^{\mathrm{ab}}$ & $7.47 \pm 0.085^{\mathrm{a}}$ & $5.91 \pm 0.250^{\mathrm{ab}}$ & $8.69 \pm 0.140^{\mathrm{b}}$ & $7.24 \pm 0.140^{\mathrm{a}}$ & $6.77 \pm 0.000^{\mathrm{a}}$ & $7.39 \pm 0.055^{\mathrm{c}}$ & $7.19 \pm 0.140^{\mathrm{a}}$ \\
F & $4.69 \pm 0.08^{\mathrm{ab}}$ & $7.36 \pm 0.025^{\mathrm{a}}$ & $5.90 \pm 0.290^{\mathrm{b}}$ & $8.86 \pm 0.025^{\mathrm{b}}$ & $9.44 \pm 0.060^{\mathrm{b}}$ & $6.69 \pm 0.080^{\mathrm{a}}$ & $7.92 \pm 0.085^{\mathrm{d}}$ & $8.86 \pm 0.140^{\mathrm{b}}$ \\
\hline
\end{tabular}

${ }^{*}$ A: $0.5 \%$ whey powder. B: $1 \%$ whey powder. C: $0.5 \%$ whey powder $+1 \%$ carob extract. D: $1 \%$ whey powder $+1 \%$ carob extract. E: $1 \%$ carob extract. F: Control; ${ }^{* a a, b, c}$ Means in the same column followed by different letters were significantly different $(\mathrm{p}<0.01)$. 
affected smoothness, taste and odour and general acceptibility of probiotic ice creams.

Survival of probiotic bacteria was also studied in probiotic ice-cream with different carob extract and whey powder concentration during 90 days. Addition of carob extract and whey powder affected viable bacteria numbers significantly. The highest number was in the samples with $1 \%$ carob extract and whey powder. Increasing carob extract and whey powder concentration stimulated the growth of L. acidophilus and Bifidobacterium BB-12. The results suggested that the addition of carob extract and whey powder stimulated the growth of L. acidophilus and Bifidobacterium BB-12 and could be recommended for ice cream production.

\section{References}

[1] Laroia, S. and Martin, J.H. (1991) Effect of pH on Survival of Bifidobacterium bifidum and Lactobacillus acidophilus in Frozen Fermented Desserts. Culture Dairy Production Journal, 26, 3-21.

[2] Hekmat, S. and McMahon, D.J. (1992) Survival of Lactobacillus acidophilus and Bifidobacterium bifidum in Ice-Cream for Use as Probiotic Food. Journal of Dairy Science, 75, 1415-1422. https://doi.org/10.3168/jds.S0022-0302(92)77895-3

[3] Haynes, I.N. and Playne, M.J. (2002) Survival of Probiotic Cultures in Low-Fat Ice-Cream. Australian Journal of Dairy Technoogy, 57, 10-14.

[4] Kailasapathy, K. and Sultana, K. (2003) Survival and $\beta$-Galactosidase Activity of Encapsulated and Free Lactobacillus acidophilus and Bifidobacterium lactis in Ice-Cream. Australian Journal of Dairy Technology, 58, 223-227.

[5] Akin, M.B., Akin, M.S. and Kirmaci, Z. (2007) Effects of Inulin and Sugar Levels on the Viability of Yogurt and Probiotic Bacteria and the Physical and Sensory Characteristics in Probiotic Ice Cream. Food Chemistry, 104, 93-99.

https://doi.org/10.1016/j.foodchem.2006.11.030

[6] Da Silva, P.D.L., De Fatima Bezerra, M., Dos Santos, K.M.O. and Correia, R.T.P. (2015) Potentially Probiotic Ice Cream from Goat's Milk: Characterization and Cell Viability during Processing, Storage and Simulated Gastrointestinal Conditions. LWT-Food Science and Technoogy, 62, 452-457. https://doi.org/10.1016/j.lwt.2014.02.055

[7] Akin, M.B. and Dasnik, F. (2015) Effects of Ascorbic Acid and Glucose Oxidase Levels on the Viability of Probiotic Bacteria and the Physical and Sensory Characteristics in Symbiotic Ice-Cream. Mljekarstvo, 65, 121-129.

[8] Ravula, R.R. and Shah, N.P. (1998) Effect of Acid Casein Hydrolisate and Cysteine on the Viability of Yogurt and Probiotic Bacteria in Fermented Frozen Dairy Desserts. Australian Journal of Dairy Technology, 53, 175-179.

[9] Güler-Akin, M.B. and Akin, M.S. (2007) Effects of Cysteine and Different Incubation Temperatures on the Microflora, Chemical Composition and Sensory Characteristics of BioYogurt Made from Goat's Milk. Food Chemistry, 100, 788-793. https://doi.org/10.1016/j.foodchem.2005.10.038

[10] Rodrigues, D., Rocha-Santos, T., Sousa, S., Gomes, A.M., Pintado, M.M., Malcata, F.X., Sousa Lobo, J.M. and Freitas, A.C. (2011) On the Viability of Five Probiotic Strains When Immobilised on Various Polymers. International Journal of Dairy Technology, 64, 137-144. https://doi.org/10.1111/j.1471-0307.2010.00627.x

[11] Lourens-Hattingh, A. and Viljoen B.C. (2001) Yogurt as Probiotic Carrier Food. International Dairy Journal, 11, 1-17. https://doi.org/10.1016/S0958-6946(01)00036-X 
[12] Dakia, A., Wathelet, B. and Paquot, M. (2007) Isolation and Chemical Evaluation of Carob (Ceratonia siliqua L.) Seed Germ. Food Chemistry, 102, 1368-1374.

https://doi.org/10.1016/j.foodchem.2006.05.059

[13] Durazzo, A., Turfani, V., Narducci, V., Azzini, E., Maiani, G. and Carcea, M. (2014) Nutritional Characterisation and Bioactive Components of Commercial Carobs Flours. Food Chemistry, 153, 109-113. https://doi.org/10.1016/j.foodchem.2013.12.045

[14] Biner, B., Gubbuk, H., Karhan, M., Aksu, M. and Pekmezci, M. (2007) Sugar Profiles of the Pods of Cultivated and Wild Types of Carob Bean (Ceratonia siliqua L.) in Turkey. Food Chemistry, 100, 1453-1455. https://doi.org/10.1016/j.foodchem.2005.11.037

[15] Avallone, R., Plessi, M., Baraldi, M. and Monzani, A. (1997) Determination of Chemical Composition of Carob (Ceratonia siliqua): Protein, Fat, Carbohydrates, and Tannins. Journal of Food Composition and Analysis, 10, 166-172. https://doi.org/10.1006/jfca.1997.0528

[16] Kumazawa, S., Taniguchi, M., Suzuki, Y., Shimura, M., Kwon, M. and Nakayama, T. (2002) Antioxidant Activity of Polyphenols in Carob pods. Journal of Agricultural and Food Chemistry, 50, 373-377. https://doi.org/10.1021/jf010938r

[17] Youssef, M., El-Manfaloty, M.M. and Ali, H.M. (2013) Assessment of Proximate Chemical Composition, Nutritional Status, Fatty Acid Composition and Phenolic Compounds of Carob (Ceratonia siliqua L.). Food Chemistry, 3, 304-308.

[18] Ayaz, F.A., Torun, H., Glew, R.H., Bak, Z.D., Chuang, L.T., Presley, J.M. and Andrews, R. (2009) Nutrient Content of Carob Pod (Ceratonia siliqua L.) Flour Prepared Commercially and Domestically. Plant Foods for Human Nutrition, 64, 286-292. https://doi.org/10.1007/s11130-009-0130-3

[19] Dave, R.I. and Shah, N.P. (1997) Effectiveness of Ascorbic Acid as an Oxigen Scavenger in Improving Viability of Probiotic Bacteria in Yoghurts Made with Commercial Starter Cultures. International Dairy Journal, 7, 435-443. https://doi.org/10.1016/S0958-6946(97)00026-5

[20] Dave, R.I. and Shah, N.P. (1998) Ingredient Supplementation Effects on Viability of Probiotic Bacteria in Yogurt. Journal of Dairy Science, 81, 2804-2816. https://doi.org/10.3168/jds.S0022-0302(98)75839-4

[21] Klaver, F., Kingma, F. and Weerkamp, A.H. (1993) Growth and Survival of Bifidobacteria in Milk. Netherlands Milk Dairy Journal, 47, 151-164.

[22] Dave, R.I. and Shah, N.P. (1996) Evaluation of Media for Selective Enumeration of Streptococcus thermophilus, Lactobacillus delbrueckii ssp. bulgaricus, Lactobacillus acidophilu and Bifidobacteria. Journal of Dairy Science, 79, 1529-1536. https://doi.org/10.3168/jds.S0022-0302(96)76513-X

[23] Türk Standartları Enstitüsü (TSE) (1989) Yoğurt Standardı. TS 1330, Ankara.

[24] Güven, M. and Karaca, O.B. (2002) The Effects of Varying Sugar Content and Fruit Concentration on the Physical Properties of Vanilla and Fruit Ice-Cream-Type Frozen Yogurts. International Journal of Dairy Technology, 55, 27-31. https://doi.org/10.1046/j.1471-0307.2002.00034.x

[25] Aime, D.B., Arntfield, S.D., Malcolmson, L.J. and Ryland, D. (2001) Textural Analysis of fat Reduced Vanilla Ice Cream Products. Food Research International, 34, 237-246. https://doi.org/10.1016/S0963-9969(00)00160-5

[26] Düzgüneş, O., Kesici, T., Kavuncu, O. and Gürbüz, F. (1987). Arastırma ve Deneme Metotları (İstatistikMetotları II). Ankara.

[27] Homayouni, A., Azizi, A., Ehsani, M.R., Yarmand, M.S. and Razavi, S.H. (2008) Effect of Microencapsulation and Resistant Starch on Probiotic Survival and Sensory Properties of 
Synbiotic Ice Cream. Food Chemistry, 111, 50-55.

https://doi.org/10.1016/j.foodchem.2008.03.036

[28] Ferraz, J., Cruz, A., Cadena, R., Freitas, M., Pinto, U. and Carvalho, C. (2012) Sensory Acceptance and Survival of Probiotic Bacteria in Ice Cream Produced with Different Overrun Levels. Journal of Food Science, 71, 24-28. https://doi.org/10.1111/j.1750-3841.2011.02508.x

[29] Akin, M.S. (2005) Effects of Inulin and Different Sugar Levels on Viability of Probiotic Bacteria and the Physical and Sensory Characteristics of Probiotic Fermented Ice-Cream. Milchwissenschaft, 60, 297-301.

[30] Akalın, A.S. and Erisir, D. (2008) Effects of Inulin and Oligofructose on the Rheological Characteristics and Probiotic Culture Survival in Low-Fat Probiotic Ice Cream. Journal of Food Science, 73, M184-M188. https://doi.org/10.1111/j.1750-3841.2008.00728.x

[31] Ranadheera, C.S., Evans, C.A., Adams, M.C. and Baines, S.K. (2013) Production of Probiotic Ice Cream from Goat's Milk and Effect of Packaging Materials on Product Quality. Small Ruminant Research, 112, 174-180. https://doi.org/10.1016/j.smallrumres.2012.12.020

[32] Puvanenthiran, A., Williams, R.P. and Augustin, M.A. (2002) Structure and Viscoelastic Properties of Set Yoghurt with Altered Casein to Whet Protein Ratios. International Dairy Journal, 12, 383-391. https://doi.org/10.1016/S0958-6946(02)00033-X

[33] Andic, S. and Boran, G. (2015) Milk Proteins: Functionality and Use in Food Industry. In: Cirillo, G., Spizzirri, U.G. and Iemma, F., Eds., Functional Polymers in Food Science: From Technology to Biology, Volume 2: Food Processing, Wiley, Hoboken, 159-180. https://doi.org/10.1002/9781119108580.ch8

[34] Erkaya, T., Dagdemir, E. and Sengül, M. (2012) Influence of Cape Gooseberry (Physalis peruviana L.) Addition on the Chemical and Sensory Characteristics and Mineral Concentrations of Ice Cream. Food Research International, 45, 331-335.

https://doi.org/10.1016/j.foodres.2011.09.013

[35] Sofjan, R.P. and Hartel, R.W. (2004) Effects of Overrun on Structural and Physical Characteristics of Ice Cream. International Dairy Journal, 14, 255-262. https://doi.org/10.1016/j.idairyj.2003.08.005

[36] Granger, C., Legerb, A., Bareyb, P., Langendorffb, V. and Cansell, M. (2005) Influence of Formulation on the Structural Networks in Ice Cream. International Dairy Journal, 15, 255 262. https://doi.org/10.1016/j.idairyj.2004.07.009

[37] Karaca, O., Guven, M., Yasar, K., Kaya, S. and Kahyaoglu, T. (2009) The Functional, Rheological and Sensory Characteristics of Ice Creams with Various Fat Replacers. International Journal of Dairy Technology, 62, 93-99. https://doi.org/10.1111/j.1471-0307.2008.00456.x

[38] Pandya, A. and Ghodke, K. (2007) Goat and Sheep Milk Products Other than Cheeses and Yoghurt. Small Ruminant Research, 68, 193-206. https://doi.org/10.1016/j.smallrumres.2006.09.007 
Submit or recommend next manuscript to SCIRP and we will provide best service for you:

Accepting pre-submission inquiries through Email, Facebook, LinkedIn, Twitter, etc. A wide selection of journals (inclusive of 9 subjects, more than 200 journals)

Providing 24-hour high-quality service

User-friendly online submission system

Fair and swift peer-review system

Efficient typesetting and proofreading procedure

Display of the result of downloads and visits, as well as the number of cited articles

Maximum dissemination of your research work

Submit your manuscript at: http://papersubmission.scirp.org/

Or contact aim@scirp.org 